\title{
SUSTAINABLE CONCEPT APPLICATION TO WASTEWATER TREATMENT IN NURI BUILDING AT Dr. M. SALAMUN BANDUNG HOSPITAL
}

\author{
Theresia Pynkyawati ${ }^{1}$, Rd. Januargo Suwito' ${ }^{2}$, Helmi Firmansyah ${ }^{3}$, \\ M. Rachmabillah S. ${ }^{4}$ \\ 1,2,3,4 Department of Architecture, National Institute of Technology, Bandung, Indonesia \\ Corresponding author: thres@itenas.ac.id
}

Received: 18 April

2020
Revised: 24 April

2020
Article History:

Accepted: 28 April

2020
Available online: 30 April

2020

\begin{abstract}
Inpatient Installation Room (IRNA) is a facility that is owned by each hospital, which requires a source of clean water with a large capacity and produces large amounts of wastewater as well. Wastewater in the form of gray water, black water, or special wastewater can be treated before being discharged or reused as a source of recycle water. The main elements in the concept of sustainability are "reduce, reuse, and recycle", the concept can be applied to the building planning, one of which is the building utility system. The application of the concept of sustainability in the NURI building is found in the building wastewater treatment system (Gray water) as a source of recycle water that is used specifically for a flush on the toilet. The method used in this study is a descriptive method with a quantitative field data analysis approach, namely data on the number of building users, the capacity of clean water, wastewater, and recycle water, as well as the dimensions of the water reservoir. This study aims to determine and understand the effectiveness of the volume and use of space for reservoirs of clean water, wastewater, and recycle water by applying the concept of sustainability to the building wastewater treatment system in the building.
\end{abstract}

Keywords - Hospital, Wastewater, Recycle Water, Sustainability, NURI Building.

\section{Introduction}

\subsection{Background of Study}

Regulation of the Minister of Health of the Republic of Indonesia concerning hospital environmental health requirements, states that: "Hospital is a means of health care, a gathering place for sick and healthy people, or can be a place of disease transmission and allow for environmental pollution and health problems" (Indonesian Minister of Health, 2004). Every hospital has an Inpatient Installation Room (IRNA) facility that requires a source of clean water with a large capacity to support all activities in it, especially the needs of patients such as bathing and defecating. The use of plenty of clean water will also produce large amounts of wastewater in the form of gray water, black water, and special wastewater. The application of the concept of Sustainable Building Utility refers to several aspects of green building development according to the Green Building Council of Indonesia (GBCl) one of which is "Water Conservation" and "Building \& Environment Management" (GBCl, 2019). Dr. M. Salamun Bandung Hospital is one of the hospitals included in the class B general hospital classification. The IRNA room in this hospital is divided into 6 buildings, one of which is the NURI building with class III inpatient facilities. This building consists of 3 floors with 15 rooms, each containing 4 beds. The application of sustainable elements in this building is "reduce" by reducing wastewater that must be disposed and reducing the use of clean water, "reuse" by reusing wastewater (Gray water) for treatment, and "recycle" by recycling wastewater (Gray water) into a special source of water to flush the toilet in the NURI building. 
The purpose of this study is to determine and understand the effectiveness of the volume and amount of space used for reservoirs of clean water, wastewater, and recycle water by applying the concept of sustainability to the building wastewater treatment system in the NURI building.

\subsection{Hospital Function Zone}

The zone in the hospital building is divided into several sections according to its function, the division of the zone has several different clean water requirements. According to Isadore Rosenfield in his book "Hospitals Integrated Design", the hospital building is divided into several zones as in Figure 1.

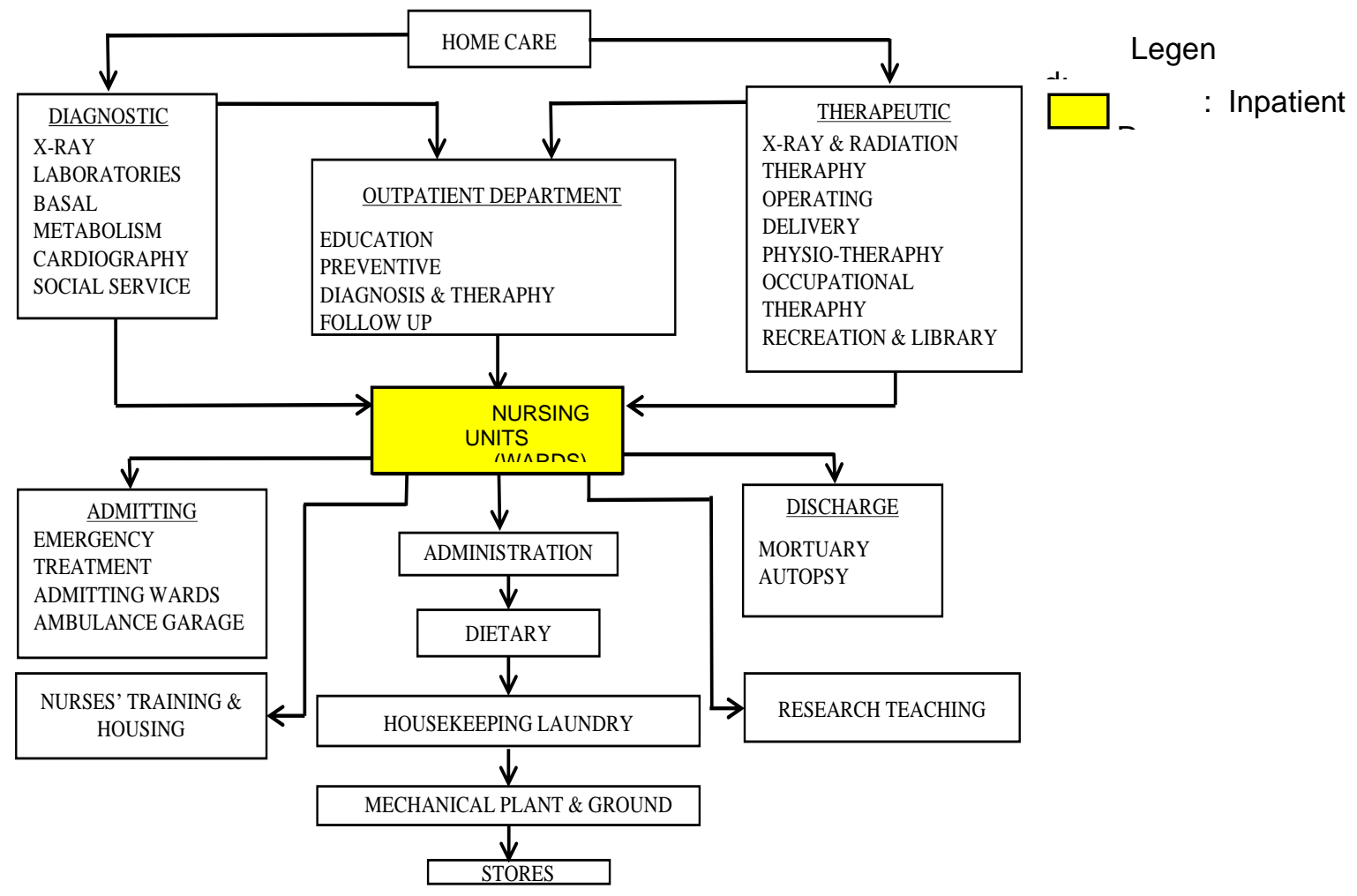

Figure 1. Rosenfield, I., Hospital Function Zone, 1956, Diagram.

Source: Hospitals Integrated Design, pp. 39

\section{Theoritical Framework}

\subsection{Sustainable Building Utility}

Sustainable architecture is an architecture that meets the needs of the present without endangering the ability of future generations to meet their own needs, those needs differing from one community to another, from one region to another and is best when determined by the relevant community (Steele,1997).

Based on this understanding, it can be concluded that sustainable building utility is a concept that has the same core as sustainable architecture, but the concept is more conical in matters relating to the utility systems in buildings.

\subsection{Clean Water}

\subsubsection{Clean Water Sources.}

The main sources of clean water are divided into 3 categories, namely rainwater that seeps into the ground, lake water, and river water. There are 2 types of clean water distribution systems, namely the "Up Feed system" and the "Down Feed system" (Pynkyawati \& Wahadamaputera, 2015, pp. 23-25). The up-feed system distributes water sourced from reservoirs located on the ground floor or underground (Figure 2), while the Down Feed system distributes water that is stored in reservoirs located on the upper floors using the help of a booster pump (Figure 3). In the down feed system, the ratio of volume to the upper reservoir and the lower reservoir is 1:2. 


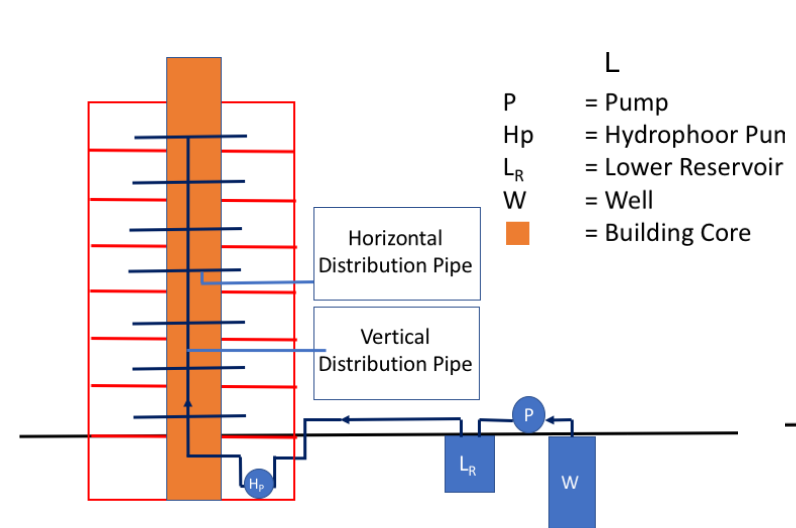

Figure 2. Pynkyawati \& Wahadamaputera, Up Feed Clean Water Distribution, 2015, Scheme. Source: Plumbing Module Building Utility, pp. 26

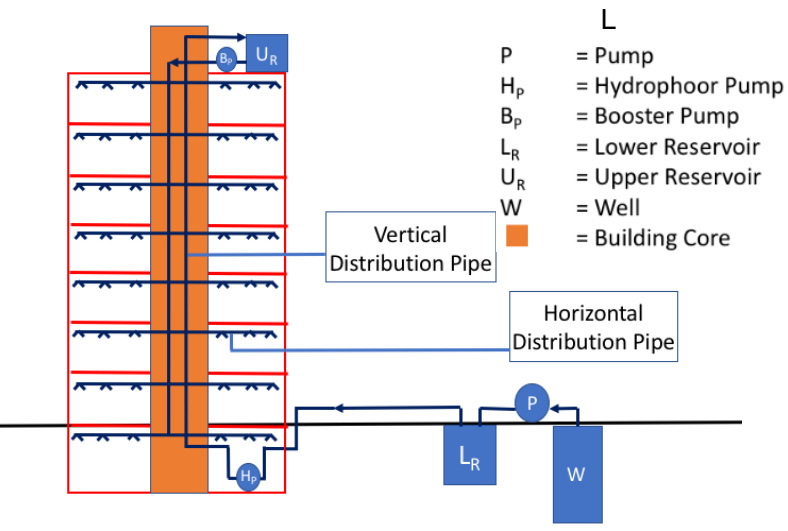

Figure 3. Pynkyawati \& Wahadamaputera, Down Feed Clean Water Distribution, 2015, Scheme. Source: Plumbing Module Building Utility, pp. 23

\subsubsection{Clean Water Needs.}

To calculate the amount of clean water needs and reservoir dimensions needed, you can use the following formula (Pynkyawati \& Wahadamaputera, 2015, pp. 33):

a. Daily Total Clean Water Needs Volume (VT)

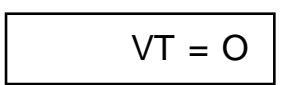

b. Minimum Reservoir Volume (VR)

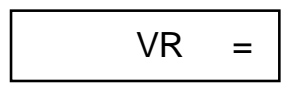

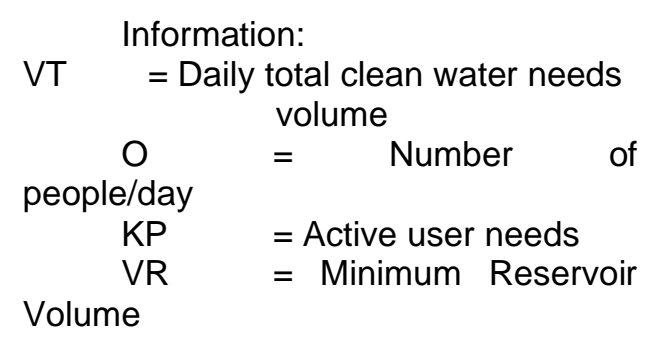

$$
\begin{array}{cl}
\mathrm{O} & =\quad \text { volume } \\
\mathrm{people} / \text { day } & = \\
\mathrm{KP} & =\text { Active user needs }
\end{array}
$$$$
\text { to the function of the building, in hospita }
$$

The need for clean water can vary according to the function of the building, in hospital buildings especially in inpatient rooms the need for clean water is 500 liters/bed/day (SNI, 2005) which can be seen in table 1 .

Table 1. Clean Water Needs According to Building Function, 2005

\begin{tabular}{lcl}
\multicolumn{1}{c}{ Building Users } & Water Usage & Unit \\
\hline Residential Home & 120 & Liter/occupant/day \\
\hline Apartment & 100 & Liter/occupant/day \\
\hline Dormitory & 120 & Liter/occupant/day \\
\hline Hospital & 500 & Liter/patient bed/day \\
\hline Elementary School & 40 & Liter/student/day \\
\hline Junior High School & 50 & Liter/student/day \\
\hline High School and Equivalent & 80 & Liter/student/day \\
\hline Shop House & 100 & Liter/occupant and employee/day \\
\hline Office/Factory & 50 & Liter/employee/day \\
\hline Department Store & 5 & Liter/m ${ }^{2}$ \\
\hline Restaurant & 15 & Liter/chair \\
\hline Star Hotel & 250 & Liter/bed/day \\
\hline Budget hotel/Lodging & 150 & Liter/bed/day \\
\hline Theater/Cinema & 10 & Liter/chair \\
\hline Multipurpose Building & 25 & Liter/chair \\
\hline Train Station/Bus Terminal & 3 & Liter/passengers arrive and leave \\
\hline Worship Places & 5 & Liter/person (not with ablution water) \\
\hline
\end{tabular}




\subsection{Wastewater}

\subsubsection{Types of Wastewater and Disposal Systems.}

There are 4 types of wastewater, namely gray water, black water, stormwater, and special wastewater. The wastewater disposal system is divided into 8 types, including the city sewage system, the regular septic tank system, septic tank system with recharge, city septic tank and sewage system, septic tank and up-flow filter system, biotech septic tank system, sewerage system with joint treatment, and sewerage system with treatment per unit (Pynkyawati \& Wahadamaputera, 2015, pp. 57-58).

\subsubsection{Gray Water.}

Every day 1 person discharges 124 liters of gray water (BPPT, 2014). Gray water can be directly disposed of or can be reprocessed into recycle water, gray water disposal channel that is water flowed through the junction box, then flows through up-flow filters and biotech filters, then the water flowed into the control basin until finally discharged into the city sewers as shown in Figure 4.

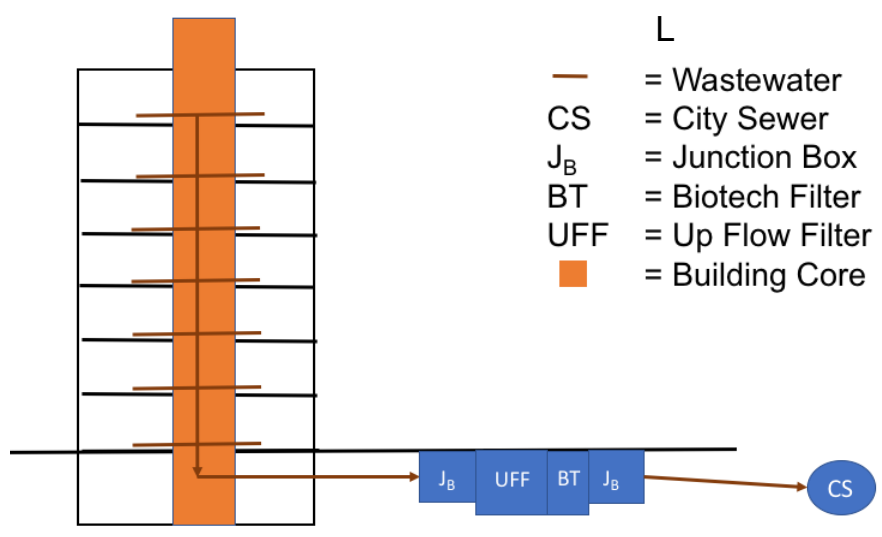

Figure 4. Pynkyawati \& Wahadamaputera, Gray Water Disposal, 2015, Scheme. Source: Plumbing Module Building Utility, pp. 93

\subsubsection{Recycled Water.}

In general, processing gray water into recycled water consists of 3 methods, namely physical, chemical, and biological processing (March, Gual, \& Orozco, 2004). The 3 wastewater treatment methods can be applied separately or can be combined.

a. Physical Processing. This process is the initial stage of wastewater treatment before further treatment of wastewater is carried out, with the aim that large suspended and easily deposited materials or floating materials are set aside first. Some physical treatment processes that can be used for domestic gray water treatment include screening, sedimentation, flotation, and others.

- The screening process is usually the first waste treatment unit to prevent solid material such as leaves and other objects that cannot be decomposed so that it does not interfere with the processing process at a later stage.

- The sedimentation process id the deposition of colloidal particles and gravity is suspended on condition that the specific gravity of the particles is greater than the density of water. If smaller particles still found, the sedimentation process is usually accompanied by a coagulation process with the addition of coagulant to bind the particles so they can settle.

- The flotation process is widely used to set aside floating materials such as oil and fat so as not to interfere with subsequent processing.

b. Chemical Processing. Chemical wastewater treatment is usually done to remove particles that do not easily settle, heavy metals, phosphorous compounds, and toxic organic substances by applying certain chemicals needed. Some chemical treatment processes that can be used to treat gray water waste include coagulation-flocculation, ion exchange, and activated carbon.

c. Biological Processing. This process is generally used for removing pollutants in the form of organic substances. Biological treatment is the most inexpensive and effective secondary treatment in removing organic substances present in wastewater.

The processed gray water into recycle water can be used for various needs, one of which is as a source of water to flush the toilet. Each person makes an average of 4 flushes in 1 day (Dietemann \& Goodman, 2002). 


\section{Method}

This research uses descriptive method with quantitative data analysis approach, where the analysis is done by comparing data in the form of the number of building users, calculations of the volume of clean water requirements, gray water discharge volume, recycle water volume, and the amount of space used for the reservoir, which is obtained at the observation location with the results of the analysis.

This comparison affects the calculation of the effectiveness of volume and use of space for the reservoir used in the NURI building by applying the concept of sustainability to the building wastewater treatment system (Gray water) as a special water source for flush on the toilet in the building.

\section{Results and Study}

\subsection{Clean Water Volume}

The number of beds in the NURI Building is 60 beds and for water needs in the inpatient room is 500 liters/bed/day (SNI,2005). Gedung NURI RSAU Dr. M. Salamun uses a Ground Water Tank (GWT) or lower reservoir which is made from Fiber Reinforced Polymer (FRP) located on the side of the building. The clean water needs in this building can be calculated as follows:

Clean water needs $=\mathrm{O} \times \mathrm{KP}$

$$
\begin{aligned}
& =60 \text { beds } \times 500 \text { liters } / \text { bed } / \text { day } \\
& =30.000 \text { liters } / \text { day } \\
& =30 \mathrm{~m}^{3} / \text { day. }
\end{aligned}
$$

The total volume of clean water based on field data is $48 \mathrm{~m}^{3}$, which consists of $15 \mathrm{~m}^{3}$ upper reservoir and $33 \mathrm{~m}^{3}$ lower reservoir. The ratio of volume ratio for upper and lower reservoirs is $1: 2$ (Pynkyawati \& Wahadamaputera, 2015, pp. 23). Based on the results of the analysis conducted and using a ratio of $1: 2$, the total volume of clean water needs in this building is $30 \mathrm{~m}^{3}$, which consists of $10 \mathrm{~m}^{3}$ upper reservoir and $20 \mathrm{~m}^{3}$ lower reservoir. The results of these calculations have a difference of $18 \mathrm{~m}^{3}$ or equivalent to $37.5 \%$ of the data in the field totaling $48 \mathrm{~m}^{3}$, thus the data in the field meet the minimum volume requirements required. The difference is prepared as a water reserve for safety factors, namely the use of water outside the prediction that is situational so that it requires more space for spare.

The upper and lower reservoirs in this building use the module form $1 \mathrm{~m} \times 1 \mathrm{~m} \times 1 \mathrm{~m}$ as in Figure 5, with the module arrangement in the lower reservoir following the shape of the land that tends to cone as shown in Figure 6.

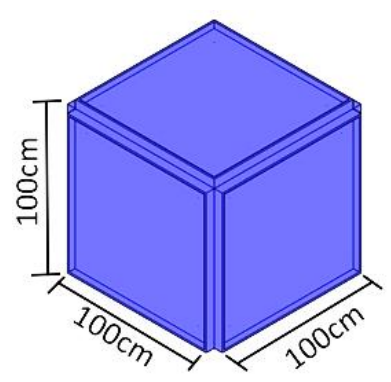

Figure 5. Reservoir Module, 2020, Drawing. Source: Authors

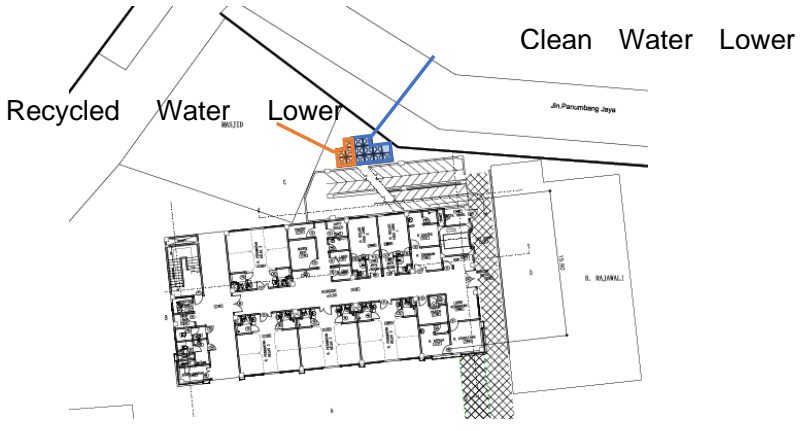

Figure 6. Plan of Placement of a Clean Water Lower Reservoir, 2020, Drawing. Source: Authors

Based on the volume obtained from the analysis, the number of modules in the reservoir under clean water in the field is 13 more than the number of modules needed. This shows that the dimensions of the clean water reservoir in the field have met the needs of clean water capacity, with an additional capacity of $13 \mathrm{~m}^{3}$ which can be seen in Figure 7. 


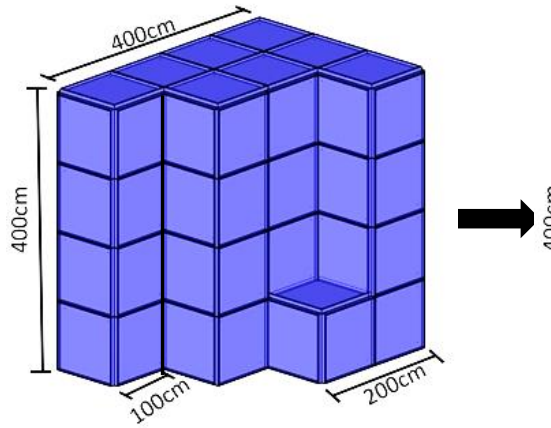

33 Modules $=$ $33 \mathrm{~m}^{3}$

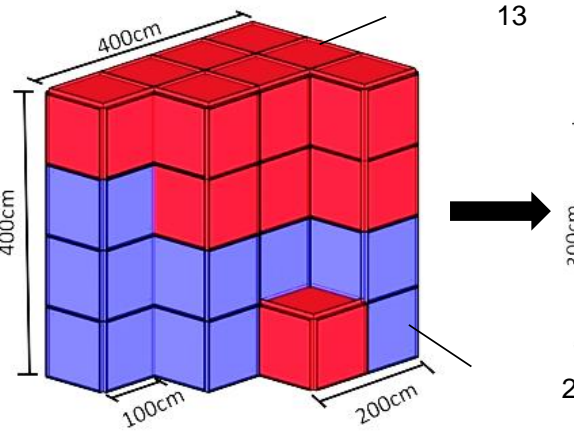

33 Modules -13 Modules $=20$

\section{Modules}

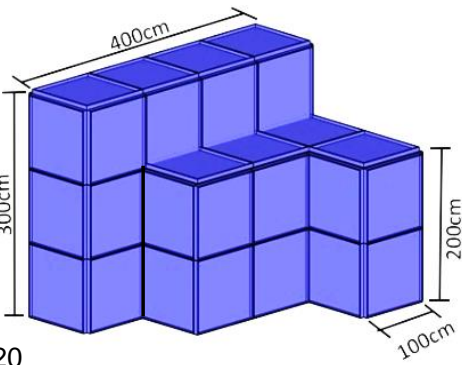

20 Modules $=$ $20 \mathrm{~m}^{3}$

Figure 7. Shape and Dimension Transformation of Clean Water Lower Resevoir, 2020, Drawing.

Source: Authors

The roof tank or upper reservoir is located on the roof floor of the building and uses the same material as the lower reservoir, FRP with dimensions of $3 \mathrm{~m} \times 5 \mathrm{~m} \times 1 \mathrm{~m}$. The upper reservoir for clean water and recycled water are placed side by side on the roof floor of the building as can be seen in the floor plan in Figure 8 and the section in Figure 9.

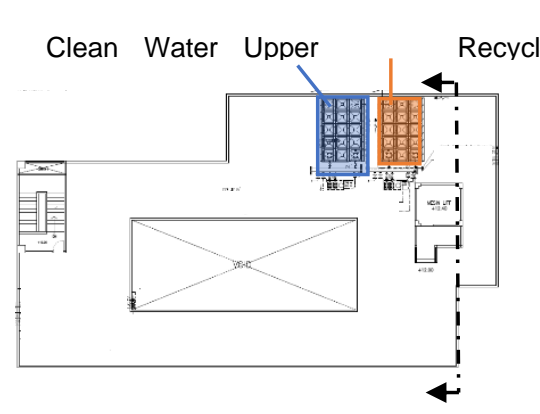

Figure 8. Plan of Placement of a Clean Water Lower Reservoir, 2020, Drawing. Source: Authors

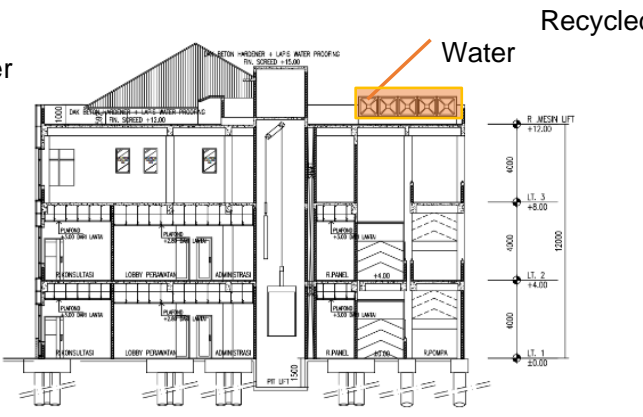

Figure 9. Section A-A Placement of Recycled Water Upper Reservoir at the Building Rooftop, 2020, Drawing.

Source: Authors

The upper reservoir also uses the same module as the lower reservoir, which is $1 \mathrm{~m} \times 1 \mathrm{~m} \mathrm{x}$ $1 \mathrm{~m}$ with a rectangular module arrangement. Based on the volume obtained from the analysis, the number of reservoir modules for clean water in the field is more than 5 modules than the number of modules needed. This shows that the reservoir dimensions of clean water in the field have met the needs of clean water capacity, with an additional capacity of $5 \mathrm{~m}^{3}$ which can be seen in Figure 10 .

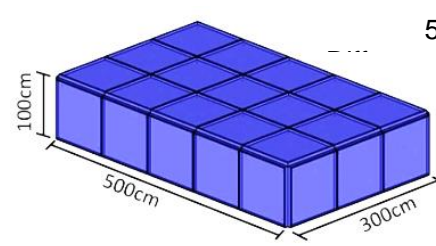

15 Modules $=$ $15 \mathrm{~m}^{3}$

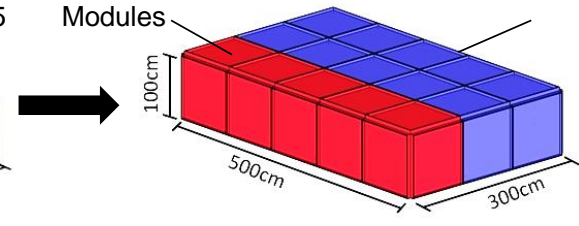

15 Moduls -5 Modules $=10$
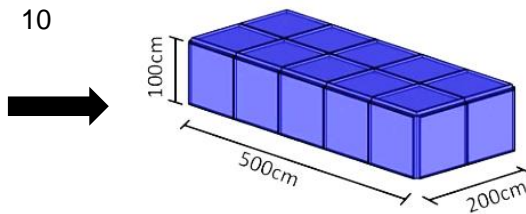

10 Modules $=$ $10 \mathrm{~m}^{3}$

Figure 10. Shape and Dimension Transformation of Clean Water Upper Resevoir, 2020,

$$
\text { Drawing. }
$$

Source: Authors

\subsection{Wastewater Volume}

Wastewater (Gray water) sourced from the floor drain and sink is reused as a source of water to flush the toilet in the NURI Building. Gray water is channeled into a neutralization tub for treatment, 
then treated water is flowed into an underwater recycle reservoir for storage. The water flows again into the reservoir over the recycle water and then distributed to each toilet in the NURI building. The number of beds in the NURI Building is 60 beds each for 1 patient and 1 patient guard, so the total number of NURI Building users is 120 persons. On average 124 liters of gray water are discharged by 1 person every day (BPPT, 2014), then the volume of gray water that is recirculated for toilet flushes in 1 day can be determined from the following calculation:

Total quantity of gray water $=$ Quantity of gray water/person/day $\times 0$

$=124$ liters/person/day $\times 120$ people

$=14.880$ liters $/$ day

$=14,88 \mathrm{~m}^{3} /$ day

$\approx 15$ Modules

Based on the above calculation, the total amount of gray water recirculated for toilet flush in the NURI Building every day is $14.88 \mathrm{~m}^{3}$. The minimum storage capacity needed is $14.88 \mathrm{~m}^{3}$ or equivalent to 15 reservoir modules.

\subsection{Recycled Water Volume}

There are many types of toilets that can be used in buildings, the types of toilets used in this building are toilets that use water tanks with a capacity of 5-6 liters for each flush. Each person makes an average of 4 flushes in 1 day (Dietemann \& Goodman, 2002). Therefore, the total volume of recycled water used for flush toilet in one day is:

Needs of water for daily flushing $\quad=\mathrm{O} x$ tank capacity/flush $\mathrm{x}$ total flush/person/day

$=120$ people $\times 6$ liters $\times 4$ flush/person/day

$=2.880$ liters $/$ day

$=2,88 \mathrm{~m}^{3} /$ day

$\approx 3$ Modules

Based on the above calculation, the requirement for recycled water volume used for toilet flush is $2.88 \mathrm{~m}^{3}$ with a minimum storage capacity equivalent to 3 reservoir modules.

The recycle underwater reservoir is placed next to the underwater reservoir and the Wastewater Treatment Plant (WWTP) is placed in the site area as shown in Figure 11.

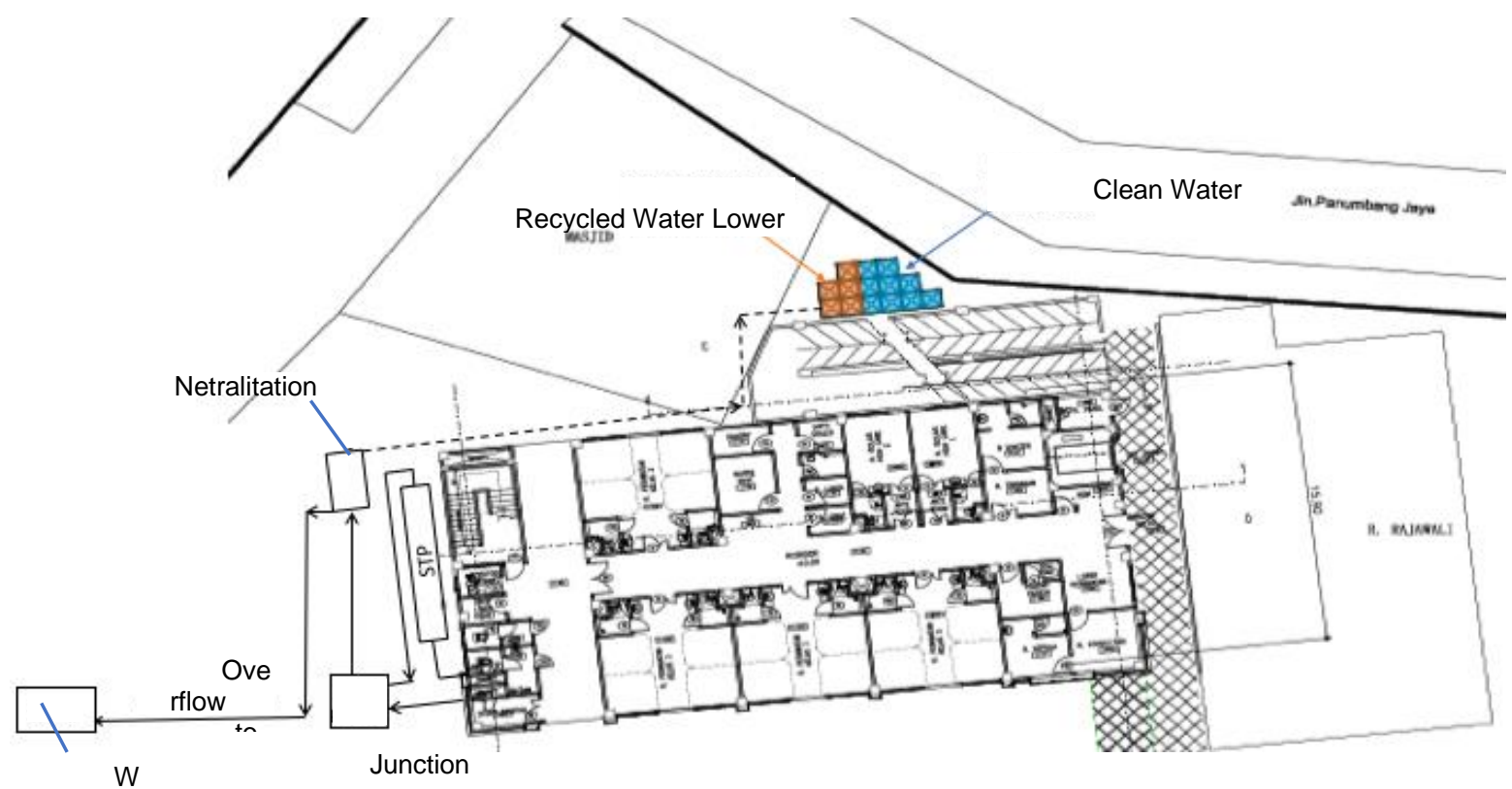

Figure 11. Plan of Placement of a Water Lower Reservoir and WWTP, 2020, Drawing.

Source: Authors

The volume of recirculated gray water is greater than the volume of water needed to flush the toilet. In the initial plan, the recycled water was not only used to flush the toilet, but it would also be used to water the plants, but it was feared that if there was a tap in the park, ordinary hospital visitors would use the faucet in the park to wash their hands so that when the implementation of the plan was not carried out. 
In the field data, the recycled water reservoir has a maximum total capacity of $35 \mathrm{~m}^{3}$ consisting of $15 \mathrm{~m}^{3}$ upper reservoir and $20 \mathrm{~m}^{3}$ lower reservoir. The ratio of volume ratio for upper and lower reservoirs is 1:2 (Pynkyawati \& Wahadamaputera, 2015, pp. 23). Based on the results of the analysis and using a ratio of $1: 2$, the total volume of recycle water reservoir needed is $15 \mathrm{~m}^{3}$ or equivalent to 15 modules consisting of $5 \mathrm{~m}^{3}$ upper reservoir and $10 \mathrm{~m}^{3}$ lower reservoir. The results of the analysis have a difference of $20 \mathrm{~m}^{3}$ or equivalent to $57.14 \%$ of the field data totaling $35 \mathrm{~m}^{3}$, thus the data in the field meet the minimum volume requirements required.

When the reservoir is full, the recycled water that is not accommodated will be discharged through an overflow pipe to the WWTP in the site area. The average total volume of recycled water that is discharged to WWTP every day is:

Wasted recycled water volume $=$ Total amount of gray water - Water needs for toilet flush/day

$$
\begin{aligned}
& =14,88 \mathrm{~m}^{3}-2,88 \mathrm{~m}^{3} \\
& =12 \mathrm{~m}^{3}
\end{aligned}
$$

Based on the above calculation, the average total volume of recycled water discharged to the WWTP every day in a full reservoir state is $12 \mathrm{~m}^{3}$. Efficient use of clean water for toilet flush that has been replaced by recycled water is $2.88 \mathrm{~m}^{3}$ per day. The recycled water lower reservoir based on the analysis has a volume of $10 \mathrm{~m}^{3}$, the volume is smaller than the field data which is a difference of $10 \mathrm{~m}^{3}$ which can be seen in Figure 12 .

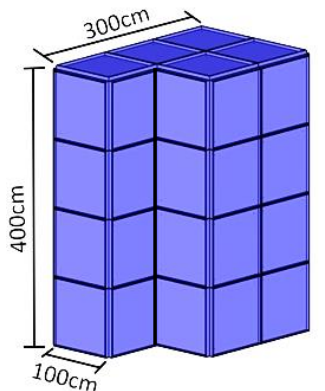

20 Modules $=$ $20 \mathrm{~m}^{3}$

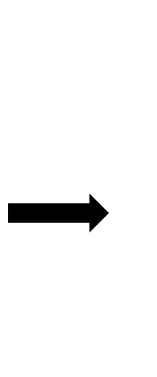

20 Modules -10 Modules $=10$

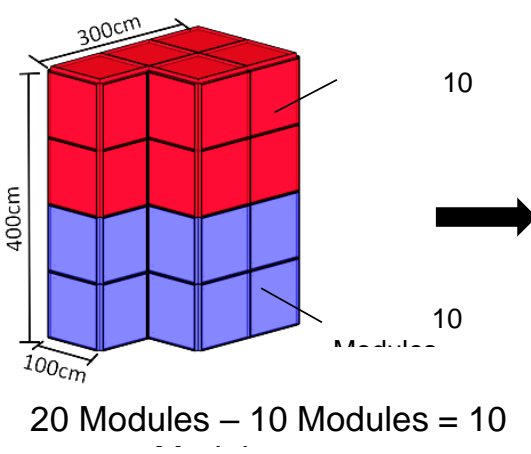

Modules

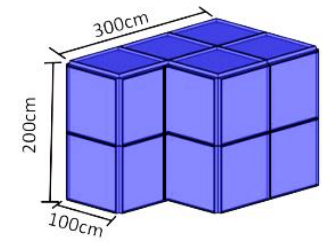

10 Modules $=$ $10 \mathrm{~m}^{3}$

Figure 12. Shape and Dimension Transformation of Recycled Water Lower Resevoir, 2020, Drawing.

Source: Authors

The roof tank or upper reservoir for recycled water is located on the roof floor of the building which can be seen in Figure 13, and uses the same material as the lower reservoir, FRP with dimensions of $3 \mathrm{~m} \times 5 \mathrm{~m} \times 1 \mathrm{~m}$. Based on the analysis of reservoir water recycle, the volume has a volume of $5 \mathrm{~m}^{3}$, the volume is smaller than the field data, with a difference of $10 \mathrm{~m}^{3}$, which can be seen in Figure 14.

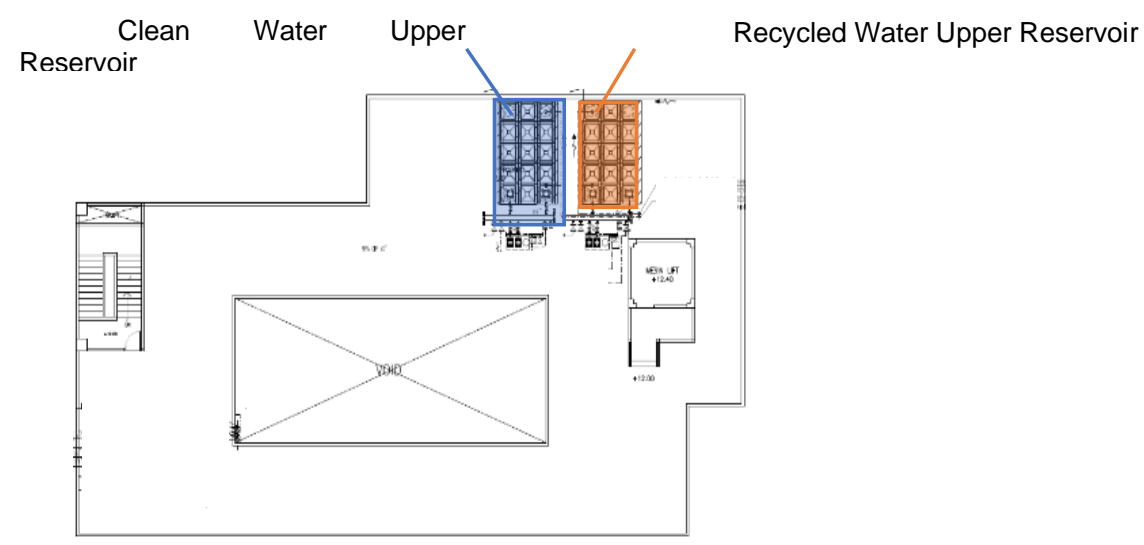

Figure 13. Plan of Placement of a Recycled Water Upper Reservoir, 2020, Drawing. Source: Authors 


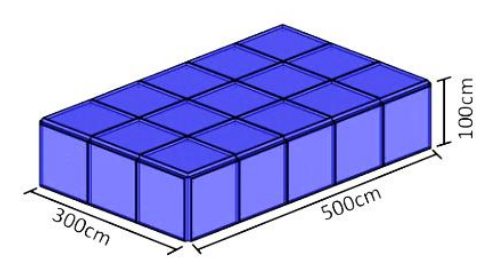

15 Modules $=$ $15 \mathrm{~m}^{3}$

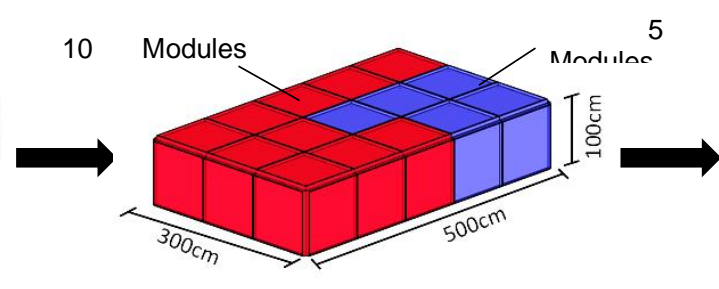

15 Modules -10 Modules $=5$

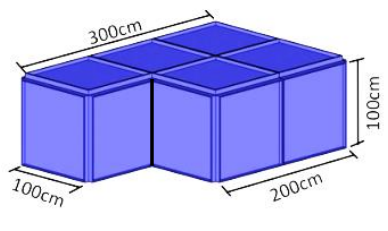

5 Modules

$=5 \mathrm{~m}^{3}$

Figure 14. Shape and Dimension Transformation of Recycled Water Upper Resevoir, 2020, Drawing.

Source: Authors

\subsection{Wastewater Treatment System}

The flow of wastewater treatment (Gray water) sourced from the floor drain and sink flows through the junction box to the neutralization tank for treatment. Treated water flows into the recycled water lower reservoir to be collected. The recycled water then flows into the upper reservoir and then distributed as a source of water to flush each toilet in the NURI Building. When the recycled water reservoir is full, the recycled water from the neutralization tank that is not accommodated in the reservoir is immediately discharged through the overflow pipe to the WWTP in the site area as in Figure 15.

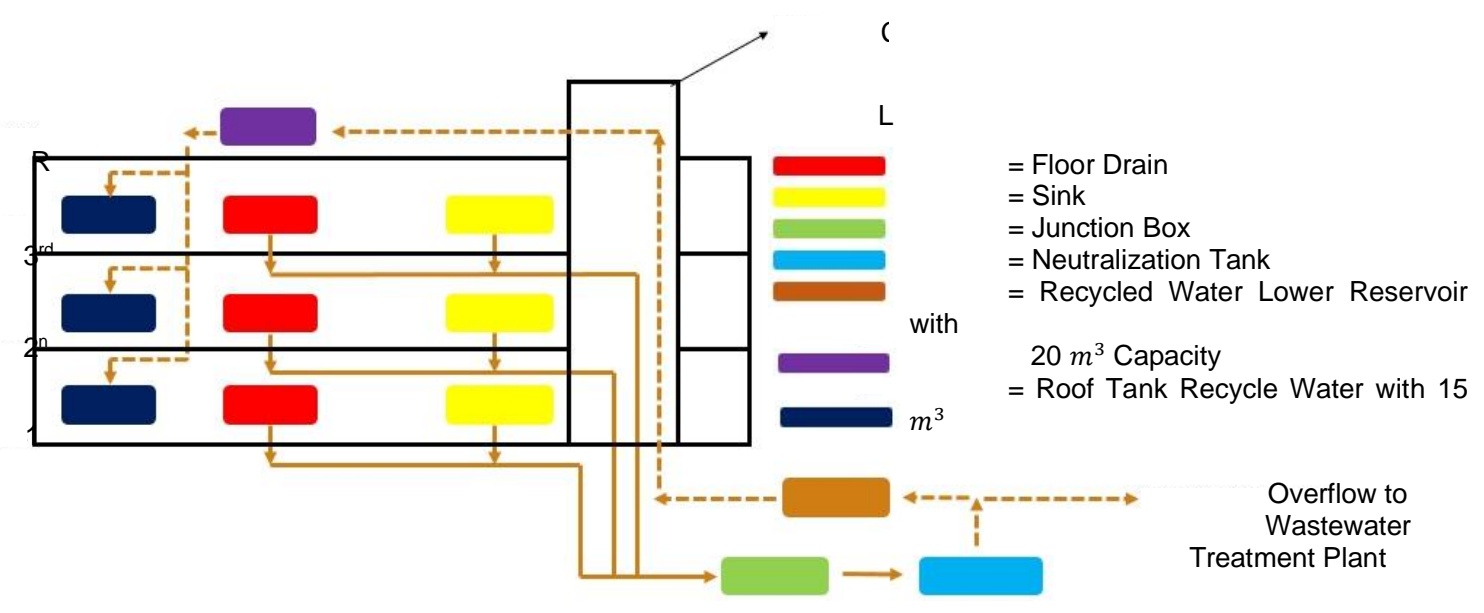

Figure 15. Gray Water Processing and Recycled Water Distribution, 2020, Scheme. Source: Authors

The wastewater treatment method (Gray water) in the NURI building uses a physical treatment method with a neutralization tank. The physical processing processes include screening, sedimentation, and flotation (March, Gual, \& Orozco, 2004). The recycled water produced from the treatment process is used specifically only as a source of water to flush the toilet. Water sources for jet washer needs in each toilet still use clean water sources.

\section{Conclusion}

The conclusions that can be drawn based on the results of the analysis related to several factors in the NURI Building that meet the sustainable concept, including:

1. The application of the concept of sustainable building utility in this building is found in the treatment and utilization system of building wastewater which only treat gray water as a source of water for flush systems in the toilet, to minimize the use of clean water and also minimize the quantity of wastewater that is wasted.

2. The difference in the volume of clean water requirements based on the results of the analysis is $18 \mathrm{~m}^{3}$ or equal to $37.5 \%$ of the field data. The difference is prepared as a water reserve for safety factors, namely the use of water outside the prediction that is situational so that it requires more space for storage. The addition of the dimensions of the lower reservoir for safety needs is done 
vertically because there is no available space on the ramp side of the building, while the addition of the upper reservoir dimension is done horizontally because there is still space on the roof floor of the building.

3. The difference in the total volume of recycle air based on the results of the analysis is $20 \mathrm{~m}^{3}$ or equal to $57.14 \%$ of the field data. In the initial plan, the recycled water was not only used to flush the toilet, but it would also be used to water the plants, but it was feared that if there was a tap in the park, ordinary hospital visitors would use the tap in the park to wash their hands, so that when the implementation of the plan was not carried out. When the reservoir is full, the recycled water that is not accommodated will be discharged through an overflow pipe to the WWTP in the site area. The average total volume of recycled water discharged to the WWTP every day is $12 \mathrm{~m}^{3}$.

4. The efficient use of clean water for the toilet flush that has been replaced by recycled water is $2.88 \mathrm{~m}^{3}$ per day. Placement of the lower reservoir for both clean water and recycle water utilizes the remaining space in the site area so that the use of space at the site becomes more effective.

\section{Acknowledgment}

This journal of architectural research was created to describe the results of research that has been done. Let the writing team thank you profusely to: (1) Staff of PT. Total Cakra Alam who has been willing to provide complete data to the authors for this architectural journal. (2) Dr. M. Salamun Bandung Hospital who has been willing to allow us to make NURI building as the object of research for this architectural journal.

\section{References}

Regulation of the Minister of Health of the Republic of Indonesia No. 1204/MENKES/SK/X/2004.

GBCl (Green Building Council Indonesia). (2019, October 29). Greenship. Retrieved from https://www.gbcindonesia.org/greenship

Rosenfield, I. (1956). Hospitals Integrated Design Second Edition. Michigan: Reinhold.

Steele, J. (1997). Sustainable Architecture: Principles, Paradigms, and Case Studies. New York: Mc-Graw Hill.

Pynkyawati, T., \& Wahadamaputera, S. (2015). Utilitas Bangunan Modul Plumbing [Plumbing Module Building Utility]. Jakarta: Griya Kreasi.

SNI (Indonesian National Standard). 03-7065-2005.

BPPT (Technology Assessment and Application Agency). (2014).

March, J.G., Gual, M., Orozco, F. (2004). Experiences on Greywater Re-use for Toilet Flushing in a Hotel (Vol. 164, No. 3, pp. 241-247). Mallorca Island, Spain: Desatination.

Dietemann, A., Goodman, J. (2002). Overview of Retrofit Strategie-a guide for Apartment Owners and Managers. San Fransisco, CA: Water Resources Engineering Inc. 